\title{
HUBUNGAN STATUS GIZI DAN KESEHATAN DENGAN KUALITAS HIDUP LANSIA DI DUA LOKASI BERBEDA
}

\author{
Relationship Nutritional and Health Status with Quality of Life of Elderly \\ in Two Research Areas
}

\author{
Nursilmi, Clara M. Kusharto, Cesilia Meti Dwiriani \\ Departemen Gizi Masyarakat, Fakultas Ekologi Manusia, Institut Pertanian Bogor
} (nursilmi12@gmail.com)

\begin{abstract}
ABSTRAK
Kualitas hidup lansia dipengaruhi oleh status gizi dan penyakit. Penelitian ini bertujuan mengidentifikasi perbedaan karakteristik subjek, status gizi, status kesehatan dan kualitas hidup serta mengkaji hubungan status gizi dan kesehatan dengan kualitas hidup lansia di Desa Ciherang Bogor dan Desa Jambu Bengkulu Tengah, dengan pertimbangan perbedaan etnis dan kebiasaan makan. Penelitian menggunakan desain cross sectional dengan 74 subjek di masing-masing desa. Pengumpulan data karakteristik subjek, status kesehatan, status gizi dan kualitas hidup menggunakan kuesioner. Analisis data menggunakan uji mann whitney dan korelasi spearman. Terdapat perbedaan signifikan karakteristik subjek dalam hal status perkawinan, pendidikan, pekerjaan dan status tinggal $(p<0,05)$. Status gizi dan kualitas hidup yang baik pada subjek di Desa Ciherang lebih banyak dibandingkan di Desa Jambu. Terdapat perbedaan signifikan status gizi lansia $(p<0,05)$ dan tidak terdapat perbedaan signifikan status kesehatan lansia $(\mathrm{p}>0,05)$. Terdapat hubungan positif pada status gizi dengan kualitas hidup domain kesehatan fisik dan lingkungan, terdapat hubungan positif pada status kesehatan dengan kualitas hidup domain kesehatan fisik dan hubungan sosial $(\mathrm{p}<0,05)$. Status gizi berhubungan dengan kualitas hidup domain kesehatan fisik dan lingkungan, sedangkan status kesehatan berhubungan dengan kualitas hidup domain kesehatan fisik dan hubungan sosial.
\end{abstract}

Kata kunci : Status gizi, status kesehatan, kualitas hidup, lansia

\section{ABSTRACT}

Quality of life in elderly influenced by nutritional status and disease. This study aimed to identify differences in subject characteristics, nutritional status, health status, quality of life and relationship nutritional and health status with quality of life of elderly in Ciherang village Bogor and Jambu village Central Bengkulu, by considering ethnic and eating habit differences. This study is a cross sectional design using 74 subjects in each research area. Data of characteristics, health status, nutritional status and quality of life were collected using questionnaire. Data were analyzed using Mann Whitney and Spearman correlation test. There were significant differences in marital status, education, occupation and living status $(p<0,05)$. Nutritional status and quality of life in Ciherang village is better than subject in Jambu village. There was a significant difference in nutritional status $(p<0,05)$ whereas unsignificant difference in health status $(p>0,05)$. There were positive correlation between nutritional status and quality of life in term of physical and environmental domain, as well as health status and quality of life in term of physical and social domain $(p<0,05)$. Nutritional status was relate to physical and environmental domain of quality of life whereas health status relate to physical and social domain of quality of life.

Keywords : Nutritional status, health status, quality of life, elderly 


\section{PENDAHULUAN}

Keberhasilan dalam pembangunan dapat ditentukan dengan adanya peningkatan taraf hidup dan Angka Harapan Hidup (AHH) yang berdampak pada peningkatan jumlah penduduk lanjut usia (lansia). Peningkatan AHH ini berdampak pula pada penurunan penyakit infeksi dan meningkatnya penyakit tidak menular atau disebut dengan transisi epidemiologi. ${ }^{1}$ Data BPS tahun 2015 menunjukkan jumlah rumah tangga lansia di Indonesia sebanyak 16,08 juta atau $24,5 \%$ dari seluruh rumah tangga, dengan jumlah lansia 20,24 juta jiwa atau $8,03 \%$ dari seluruh penduduk. Proporsi lansia perempuan sedikit lebih banyak dibandingkan laki-laki yaitu 10,77 juta dibandingkan dengan 9,47 juta. Jumlah lansia Indonesia tahun 2025 diperkirakan sekitar 34,22 juta jiwa. ${ }^{2}$

Secara alami lansia mengalami kemunduran fisik, psikis dan sosial sehingga tergantung pada orang lain. ${ }^{3}$ Ketergantungan tersebut dapat dikurangi jika lansia sehat, aktif, produktif, mandiri dan memiliki kualitas hidup yang baik. ${ }^{4}$ WHO berharap terjadinya penuaan aktif (active ageing) yaitu proses yang memungkinkan diperolehnya kesehatan, partisipasi dan keamanan dalam upaya meningkatkan kualitas hidup lansia. ${ }^{5}$ Jika seorang lansia dapat mencapai kualitas hidup yang baik, maka kehidupannya mengarah pada keadaan sejahtera (wellbeing), sebaliknya jika kualitas hidup rendah, maka kehidupannya mengarah pada keadaan tidak sejahtera (ill-being) ${ }^{6}$

Menurut WHO kualitas hidup merupakan persepsi individu dalam kehidupan yang dijalani seseorang dengan konteks budaya dan nilai individu tersebut tinggal, termasuk aspek kesehatan fisik, keadaan psikologis, tingkat kemandirian, hubungan sosial, keyakinan pribadi dan hubungannya dengan lingkungan. ${ }^{7}$ Kualitas hidup merupakan ukuran hasil yang penting dalam kesehatan. Tingkat kualitas hidup tergantung pada latar belakang sosial ekonomi dan budaya. ${ }^{8}$ Kualitas hidup bersifat subjektif dan tidak terlihat oleh orang lain karena merupakan persepsi individu itu sendiri. $^{9}$

World Health Organization (WHO) telah mengembangkan instrumen untuk mengukur kualitas hidup yaitu WHO Quality of Life-BREF (WHOQOL BREF). ${ }^{7}$ Instrumen ini merupakan instrumen yang valid dan reliable untuk mengukur kualitas hidup lansia, tetapi masih perlu dikembangkan dan dimodifikasi. ${ }^{10}$ Mengingat gizi kurang merupakan salah satu prediktor perubahan kualitas hidup yang berhubungan dengan kesehatan. ${ }^{11}$ Kesehatan tidak hanya untuk meningkatkan harapan hidup tetapi juga meningkatkan kualitas hidup. Makanan dan gizi dapat menjadi dimensi penting dalam pengukuran kualitas hidup. ${ }^{12}$ Status gizi yang kurang atau berlebih akan mempengaruhi kualitas hidup lansia. Gizi yang baik berarti tubuh memiliki cukup zat gizi untuk mempertahankan fungsi dan gangguan kesehatan. ${ }^{11}$

Keluhan kesehatan yang sering dialami lansia yaitu asam urat, darah tinggi, rematik, darah rendah dan diabetes $(32,99 \%)$, keluhan ini merupakan keluhan efek dari penyakit kronis. ${ }^{1}$ Berdasarkan catatan dari Puskesmas, keluhan yang sering dialami lansia di Desa Ciherang dan Desa Jambu yaitu hipertensi. Kualitas hidup lansia yang menderita hipertensi lebih rendah dibandingkan dengan lansia yang memiliki tensi normal. Penyakit tidak menular akan menyebabkan masalah medis, sosial dan psikologis yang membatasi aktivitas dan menyebabkan penurunan kualitas hidup. ${ }^{13}$ Kualitas hidup lansia seharusnya menjadi perhatian penting karena dapat menjadi acuan keberhasilan dalam merumuskan intervensi bagi lansia serta digunakan sebagai indikator global dalam bidang kesehatan dan sosial. ${ }^{9}$

Masyarakat di Jawa Barat pada umumnya mempunyai kebiasaan mengonsumsi sayuran atau lalapan, sedangkan masyarakat di Bengkulu sering mengonsumsi makanan dengan rasa pedas, gurih, penggunaan santan yang kental, banyak mengandung lemak dan garam. ${ }^{14,15}$ Berdasarkan survei awal masyarakat di Desa Jambu sering mengonsumsi ikan air tawar, makanan yang mengandung santan dan minyak, sedangkan di Desa Ciherang memiliki kebiasaan makan sayur, kacangkacangan dan ikan asin. Kebiasaan makan yang tidak sehat dapat menyebabkan berbagai macam gangguan kesehatan dan mempengaruhi status gizi lansia yang akhirnya berdampak pada penurunan kualitas hidup. ${ }^{16}$ Berdasarkan hal yang telah diuraikan tersebut, maka peneliti tertarik untuk mengidentifikasi perbedaan karakteristik subjek, status gizi, status kesehatan dan kualitas hidup serta mengkaji hubungan status gizi dan kesehatan dengan kualitas hidup lansia di Desa Ciherang Bogor 
dan Desa Jambu Bengkulu Tengah.

\section{BAHAN DAN METODE}

Penelitian ini menggunakan desain cross sectional, dilakukan di Desa Ciherang Kecamatan Dramaga Kabupaten Bogor dan di Desa Jambu Kecamatan Merigi Kelindang Kabupaten Bengkulu Tengah. Pemilihan lokasi berdasarkan keadaan sosial ekonomi menengah ke bawah dan memiliki posyandu lansia yang aktif setiap bulan. Penelitian ini menggunakan sebagian data dari Penelitian Unggulan Perguruan Tinggi (PUPT) dengan judul Minyak Ikan Lele (Clarias Gariepinus) sebagai Suplement Alternatif Pencegah Alzheimer pada Lansia di Desa Ciherang, Kecamatan Dramaga Bogor. Penelitian dilakukan sejak Juni 2016 sampai dengan Januari 2017. Penarikan subjek dilakukan secara purposive yang memenuhi

Tabel 1. Sebaran Karakteristik Subjek di Desa Ciherang dan Desa Jambu

\begin{tabular}{|c|c|c|c|c|c|}
\hline \multirow{2}{*}{ Karakteristik } & \multicolumn{2}{|c|}{ Ciherang } & \multicolumn{2}{|c|}{ Jambu } & \multirow{2}{*}{$\mathbf{p}$} \\
\hline & $\mathbf{n}$ & $\%$ & $\mathbf{n}$ & $\%$ & \\
\hline \multicolumn{6}{|l|}{ Usia (tahun) } \\
\hline $45-59$ & 0 & 0 & 0 & 0 & \\
\hline $60-74$ & 65 & 87,84 & 69 & 93,24 & \\
\hline $75-90$ & 9 & 12,16 & 5 & 6,76 & \\
\hline$>90$ & 0 & 0 & 0 & 0 & \\
\hline Rata-rata \pm SD & \multicolumn{2}{|c|}{$66,92 \pm 6,19$} & \multicolumn{2}{|c|}{$63,58 \pm 5,06$} & 0,261 \\
\hline \multicolumn{6}{|l|}{ Jenis Kelamin } \\
\hline Laki-Laki & 15 & 20,27 & 24 & 30 & \multirow[t]{2}{*}{0,184} \\
\hline Perempuan & 59 & 79,73 & 56 & 70 & \\
\hline \multicolumn{6}{|l|}{ Status Perkawinan } \\
\hline Belum/tidak menikah & 0 & 0 & 0 & 0 & \multirow[t]{4}{*}{0,000} \\
\hline Menikah & 30 & 40,54 & 63 & 85,14 & \\
\hline Cerai hidup & 0 & 0 & 0 & 0 & \\
\hline Cerai mati & 44 & 59,46 & 11 & 14,86 & \\
\hline \multicolumn{6}{|l|}{ Pendidikan } \\
\hline Tidak pernah sekolah & 14 & 18,92 & 25 & 33,78 & \multirow[t]{5}{*}{0,120} \\
\hline Tidak tamat SD & 17 & 22,97 & 28 & 37,84 & \\
\hline $\mathrm{SD}$ & 35 & 47,30 & 17 & 22,97 & \\
\hline SMP & 7 & 9,46 & 3 & 4,06 & \\
\hline SMA & 1 & 1,35 & 1 & 1,35 & \\
\hline \multicolumn{6}{|l|}{ Pekerjaan } \\
\hline Tidak Bekerja & 57 & 79,73 & 38 & 51,35 & \multirow[t]{2}{*}{0,000} \\
\hline Bekerja & 15 & 20,27 & 36 & 48,65 & \\
\hline \multicolumn{6}{|l|}{ Status tinggal } \\
\hline Sendirian & 5 & 6,76 & 2 & 2,70 & \multirow[t]{4}{*}{1,000} \\
\hline Suami/istri & 16 & 21,62 & 26 & 35,15 & \\
\hline Anak & 40 & 54,05 & 14 & 18,91 & \\
\hline Suami/istri \& anak & 13 & 17,57 & 32 & 43,24 & \\
\hline \multicolumn{6}{|l|}{ Suku } \\
\hline Sunda & 68 & 85,14 & 0 & 0 & \multirow[t]{4}{*}{-} \\
\hline Betawi & 9 & 12,16 & 0 & 0 & \\
\hline Jawa & 2 & 2,70 & 2 & 2,70 & \\
\hline Rejang & 0 & 0 & 72 & 97,30 & \\
\hline \multicolumn{6}{|l|}{ Pendapatan/kapita } \\
\hline Miskin & 27 & 36,49 & 36 & 46,65 & \\
\hline Tidak miskin & 47 & 63,51 & 38 & 51,35 & \\
\hline Rata-rata \pm SD & \multicolumn{2}{|c|}{$370688 \pm 203472$} & \multicolumn{2}{|c|}{$377355 \pm 331851$} & 0,111 \\
\hline
\end{tabular}

Sumber : Data Primer, 2017 
kriteria inklusi yaitu berusia $\geq 60$ tahun, tidak mengalami gangguan pendengaran, dan bersedia untuk diwawancara. Jumlah subjek pada penelitian yaitu 148 lansia yang terdiri dari 74 subjek di Desa Ciherang dan 74 subjek di Desa Jambu.

Jenis data yang digunakan adalah data sekunder dan data primer. Data sekunder di Desa Ciherang yaitu data karakteristik subjek (usia, jenis kelamin, tingkat pendidikan, status perkawinan, suku, status tinggal, dan pekerjaan), sedangkan data primer yaitu pendapatan, Mini $\mathrm{Nu}$ tritional Assessment (MNA), riwayat penyakit, kualitas hidup. Seluruh data penelitian di Desa Jambu adalah data primer yaitu data karakteristik subjek, MNA, riwayat penyakit, dan kualitas hidup. Pengumpulan data karakteristik subjek dan riwayat penyakit dilakukan dengan wawancara langsung menggunakan kuesioner. Data status gizi diperoleh dengan menggunakan kuesioner MNA yang terdiri dari 18 pertanyaan, serta dilakukan pengukuran lingkar lengan atas (LILA), lingkar betis (LB), tinggi badan dan berat badan. Kualitas hidup diperoleh dengan wawancara menggunakan kuesioner WHOQOL BREF yang telah dimodifikasi dan divalidasi dengan nilai Alpha Cronbach 0,896 . Kuesioner ini terdiri dari lima domain, skor tiap domain (raw score) ditransformasikan dalam skala 0-100 dengan menggunakan rumus baku yang telah ditetapkan oleh WHO yaitu : Transformed Score $=\left(\right.$ Score-4) $\times(100 / 16){ }^{7}$

Pengkategorian karakeristik subjek yaitu usia 45-59 tahun, 60-74 tahun, 75-90 tahun dan $>90$ tahun. Data pendidikan terakhir dikategorikan dalam lima kelompok, yaitu tidak sekolah, tidak tamat SD, SD/sederajat, SMP/sederajat, dan SMA/sederajat. Status perkawinan dikategorikan menjadi tidak menikah, menikah, cerai hidup dan cerai mati. Pekerjaan dikategorikan menjadi tidak bekerja dan bekerja. Status tinggal dikategorikan menjadi empat yaitu sendiri, suami/istri, anak serta suami/istri dan anak. Pendapatan dikategorikan menjadi miskin dan tidak miskin. ${ }^{17}$

Status gizi dikategorikan menjadi malnutrisi jika skor $<17$, berisiko malnutrisi jika skor 17-23,5 dan gizi baik jika skor 24-30. ${ }^{18}$ Status kesehatan dilihat berdasarkan riwayat penyakit dan penyakit satu bulan terakhir. Kategori riwayat penyakit yaitu ada riwayat penyakit dan tidak ada riwayat penyakit, sedangkan penyakit satu bulan terakhir dikategorikan menjadi sakit dan tidak sakit. Kualitas hidup setiap domain dikategorikan menjadi dua yaitu kurang jika skor $\leq 50$ dan baik jika skor $>50 .{ }^{7}$

Data dianalisis menggunakan program Microsoft Excel 2013 dan SPSS for Windows versi 22.0. Analisis univariat digunakan untuk mendeskripsikan semua variabel. Analisis bivariat digunakan untuk mengetahui hubungan status gizi dan kesehatan dengan kualitas hidup serta melihat perbedaan karakteristik subjek, status gizi, status kesehatan dan kualitas hidup subjek di dua lokasi penelitian. Analisis bivariat yang digunakan yaitu korelasi spearman dan mann whitney.

\section{HASIL}

Lansia di Desa Ciherang dan Desa Jambu sebagian besar berada pada rentang usia 6074 tahun, masing-masing sebanyak $87,84 \%$ dan $93,24 \%$. Persentase lansia perempuan lebih besar dibandingkan lansia laki-laki yaitu 79,73\% di Desa Ciherang dan 70,0\% di Desa Jambu. Sebanyak 59,46\% lansia di Desa Ciherang adalah lansia dengan status cerai mati, sedangkan di Desa Jambu $85,14 \%$ lansia dengan status menikah. Sebanyak 47,30\% lansia di Desa Ciherang adalah lansia dengan status pendidikan tamat SD, sedangkan di Desa Jambu 37,84\% lansia tidak tamat SD. Lansia di Desa Ciherang dan Desa Jambu sebagian besar tidak bekerja, masing-masing sebanyak 79,73\% dan 51,35\%. Lansia di Desa Ciherang lebih banyak tinggal bersama anak $(54,05 \%)$, sedangkan di Desa Jambu lansia lebih banyak tinggal bersama suami/istri dan anak (43,24\%). Mayoritas lansia di Ciherang berasal dari suku Sunda $(85,14 \%)$, sedangkan mayoritas lansia di Jambu berasal dari suku Rejang (97,30\%). Sebagian besar lansia di Desa Ciherang dan Desa Jambu termasuk kedalam kategori tidak miskin, masing-masing sebanyak $63,51 \%$ dan $51,35 \%$ (Tabel 1). Tidak terdapat perbedaan pada usia, jenis kelamin, pendidikan, status tinggal, dan pendapatan per kapita $(p>0,05)$, tetapi terdapat perbedaan signifikan pada status perkawinan dan pekerjaan antara lansia di Desa Ciherang dan Desa Jambu $(\mathrm{p}<0,05)$.

Tabel 2 menunjukkan sebanyak $68,9 \%$ subjek di Desa Ciherang tidak mengalami penurunan asupan makan, sedangkan 52,7\% subjek di Desa Jambu mengalami penurunan asupan sedang. Subjek di Desa Ciherang sebagian besar tidak kehila- 
Tabel 2. Sebaran Subjek Berdasarkan Pertanyaan MNA

\begin{tabular}{|c|c|c|c|c|c|c|}
\hline \multirow{2}{*}{ No. } & \multirow{2}{*}{ Variabel } & \multirow{2}{*}{ Jawaban } & \multicolumn{2}{|c|}{ Ciherang } & \multicolumn{2}{|c|}{ Jambu } \\
\hline & & & $\mathbf{n}$ & $\%$ & $\mathbf{n}$ & $\%$ \\
\hline \multirow[t]{2}{*}{1} & Penurunan asupan makan selama 3 & Parah & 2 & 2,7 & 0 & 0 \\
\hline & bulan terakhir & Sedang & 21 & 28,4 & 39 & 52,7 \\
\hline \multirow[t]{3}{*}{2} & Penurunan berat badan selama 3 & Lebih dari $3 \mathrm{~kg}$ & 1 & 1,4 & 1 & 1,4 \\
\hline & bulan terakhir & Antara $1-3 \mathrm{~kg}$ & 22 & 29,7 & 8 & 10,8 \\
\hline & & Tidak tahu & 10 & 13,5 & 34 & 45,9 \\
\hline 3 & Mobilisasi & Normal & 74 & 100 & 74 & 100 \\
\hline 4 & Stress/penyakit akut 3 bulan terakhir & Tidak & 68 & 91,9 & 64 & 86,5 \\
\hline 5 & Masalah neuropsikologis & Tidak mengalami & 70 & 94,6 & 71 & 95,9 \\
\hline \multirow[t]{4}{*}{6} & Indeks massa tubuh (IMT) & $<19$ & 13 & 17,5 & 10 & 13,5 \\
\hline & & $19-21$ & 7 & 9,5 & 15 & 20,3 \\
\hline & & $21-23$ & 17 & 23,0 & 13 & 17,6 \\
\hline & & $>23$ & 37 & 50,0 & 36 & 48,6 \\
\hline 7 & Hidup mandiri (Tidak di Panti/RS) & $\mathrm{Ya}$ & 74 & 100 & 74 & 100 \\
\hline 8 & Minum obat $>3$ jenis/hari & Tidak & 66 & 89,2 & 71 & 95,9 \\
\hline 9 & Luka pada kulit & Tidak & 70 & 94,6 & 68 & 91,1 \\
\hline \multirow[t]{2}{*}{10} & Frekuensi makan setiap hari & 2 kali & 42 & 56,8 & 11 & 14,9 \\
\hline & & 3 kali & 32 & 43,2 & 63 & 85,1 \\
\hline \multirow[t]{3}{*}{11} & Konsumsi makanan sumber protein & Tidak ada/hanya 1 & 29 & 39,2 & 21 & 28,4 \\
\hline & & Jika 2 jawaban & 32 & 43,2 & 51 & 68,9 \\
\hline & & Jika semua jawaban ya & 13 & 17,6 & 2 & 2,7 \\
\hline 12 & $\begin{array}{l}\text { Konsumsi } \geq 2 \text { porsi buah/sayur setiap } \\
\text { hari }\end{array}$ & $\mathrm{Ya}$ & 45 & 62,2 & 6 & 8,1 \\
\hline \multirow[t]{2}{*}{13} & Konsumsi cairan per hari & $\leq 5$ gelas & 39 & 52,8 & 40 & 54,0 \\
\hline & & $>5$ gelas & 35 & 47,2 & 34 & 46,0 \\
\hline 14 & Cara makan & Makan sendiri & 71 & 95,9 & 74 & 100 \\
\hline \multirow[t]{3}{*}{15} & Persepsi mengenai status gizi & Ada masalah & 16 & 21,6 & 3 & 4,1 \\
\hline & & Ragu/tidak tahu & 7 & 9,5 & 8 & 10,8 \\
\hline & & Tidak ada masalah & 51 & 68,9 & 63 & 85,1 \\
\hline \multirow[t]{4}{*}{16} & Persepsi mengenai status kesehatan & Tidak lebih baik & 11 & 14,9 & 10 & 13,5 \\
\hline & & Tidak tahu & 6 & 8,1 & 25 & 33,8 \\
\hline & & Sama baiknya & 36 & 48,6 & 38 & 51,4 \\
\hline & & Lebih baik & 21 & 28,4 & 1 & 1,4 \\
\hline \multirow[t]{3}{*}{17} & Lingkar lengan atas (LILA) & $<21 \mathrm{~cm}$ & 2 & 2,7 & 3 & 4,1 \\
\hline & & $21-22 \mathrm{~cm}$ & 6 & 8,1 & 6 & 8,1 \\
\hline & & $>22 \mathrm{~cm}$ & 66 & 89,2 & 65 & 87,8 \\
\hline \multirow[t]{3}{*}{18} & Lingkar betis (LB) & $<31 \mathrm{~cm}$ & 43 & 58,1 & 22 & 29,7 \\
\hline & & $>31 \mathrm{~cm}$ & 31 & 41,9 & 52 & 70,3 \\
\hline & \multicolumn{2}{|l|}{ Rata-rata \pm SD } & \multicolumn{2}{|c|}{$25,62 \pm 2,85$} & \multicolumn{2}{|c|}{$24,80 \pm 3,23$} \\
\hline
\end{tabular}

Sumber : Data Primer 2017

ngan berat badan $(55,4 \%)$, sedangkan di Desa Jambu sebagian besar subjek tidak tahu mengalami penurunan berat badan $(45,9 \%)$. Seluruh subjek $(100 \%)$ dapat melakukan mobilitas dengan normal dan hidup sendiri (tidak di panti/RS). Lebih dari separuh subjek di kedua desa tidak mengalami stres maupun masalah neuropsikologis seperti dementia. Subjek yang memiliki Indeks Massa Tu- buh $\left(\right.$ IMT) $>23 \mathrm{~kg} / \mathrm{m}^{2}$ di Desa Ciherang sebanyak 50\% sedangkan di Desa Jambu 48,6\%. Frekuensi makan subjek di Desa Ciherang 2 kali sehari $(56,8 \%)$ sedangkan di Desa Jambu 3 kali sehari $(85,1 \%)$. Sebagian besar subjek di dua desa mengonsumsi 2 jenis asupan protein setiap hari dengan persentase $43,2 \%$ dan $68,9 \%$. Subjek di Desa Ciherang lebih sering mengonsumsi sayur atau 
Tabel 3. Sebaran Subjek Berdasarkan Status Gizi (MNA) dan Status Kesehatan

\begin{tabular}{|c|c|c|c|c|c|}
\hline \multirow{2}{*}{ Variabel } & \multicolumn{2}{|c|}{ Ciherang } & \multicolumn{2}{|c|}{ Jambu } & \multirow{2}{*}{$\mathbf{p}$} \\
\hline & $\mathbf{n}$ & $\%$ & $\mathbf{n}$ & $\%$ & \\
\hline \multicolumn{6}{|l|}{ Status gizi } \\
\hline Malnutrisi & 0 & 0 & 0 & 0 & 0,002 \\
\hline Risiko Malutrisi & 10 & 13,51 & 26 & 35,14 & \\
\hline Gizi Baik & 64 & 86,49 & 48 & 64,86 & \\
\hline Tidak ada riwayat renyakit & 28 & 37,84 & 17 & 22,97 & 0,074 \\
\hline Ada riwayat penyakit & 48 & 62,16 & 57 & 77,03 & \\
\hline Hipertensi & 24 & 32.43 & 38 & 51.35 & \\
\hline Jantung & 1 & 1,35 & 1 & 1,35 & \\
\hline Ginjal & 1 & 1,35 & 3 & 4,05 & \\
\hline Diabetes melitus & 0 & 0 & 1 & 1,35 & \\
\hline Gangguan tiroid & 1 & 1,35 & 0 & 0 & \\
\hline lainnya & 21 & 28,38 & 14 & 18,92 & \\
\hline Penyakit 1 bulan terakhir & & & & & 0,084 \\
\hline Tidak sakit & 31 & 41,89 & 20 & 27,03 & \\
\hline Sakit & 43 & 58,11 & 54 & 72,97 & \\
\hline Hipertensi & 9 & 12,16 & 14 & 18,91 & \\
\hline Rematik & 5 & 6,76 & 14 & 18,91 & \\
\hline Asam urat & 3 & 4,05 & 4 & 5,40 & \\
\hline Demam & 5 & 6,76 & 3 & 4,05 & \\
\hline Batuk & 4 & 5,40 & 3 & 4,05 & \\
\hline Sakit kepala & 7 & 9,46 & 5 & 6,76 & \\
\hline Lainnya & 10 & 13,51 & 11 & 14,86 & \\
\hline
\end{tabular}

Sumber : Data Primer, 2017

buah 2 porsi perhari dibandingkan subjek di Desa Jambu. Sebagian besar konsumsi cairan subjek di Desa Ciherang dan Desa Jambu $\leq 5$ gelas per hari dengan persentase $52,8 \%$ dan $54 \%$. Lebih dari separuh subjek di dua desa merasa tidak ada masalah mengenai status gizi dan memiliki persepsi kesehatan yang sama baiknya dengan orang lain.

Tabel 3 menunjukkan sebagian besar lansia di Desa Ciherang dan di Desa Jambu memiliki status gizi yang baik yaitu sebesar $86,49 \%$ dan 64,86\%. Lansia dengan risiko malnutrisi di Desa Jambu lebih banyak dibandingkan Desa Ciherang yaitu $35,14 \%$. Terdapat perbedaan signifikan status gizi lansia di Desa Ciherang dan Desa Jambu $(p<0,05)$. Sebagian besar lansia di Desa Ciherang dan Desa Jambu memiliki riwayat penyakit yaitu masing-masing sebesar $62,16 \%$ dan $77,03 \%$, serta menderita sakit dalam satu bulan terakhir dengan persentase $58,11 \%$ dan $72,97 \%$. Tidak terdapat perbedaan signifikan pada riwayat penyakit dan penyakit satu bulan terakhir antara lansia di Desa Ciherang dan Desa Jambu ( $>00,05)$.

Tabel 4 menunjukkan domain kesehatan fisik, psikologis, lingkungan, hubungan sosial dan gizi sebagian besar lansia di Desa Ciherang masuk dalam kategori kualitas hidup baik dengan persentase berturut-turut yaitu $66,21 \%, 62,16 \%$, $58,11 \%, 51,35 \%$ dan $95,95 \%$. Berbeda hal-nya dengan di Desa Jambu, sebagian besar lansia memiliki kualitas hidup yang kurang pada domain kesehatan fisik, lingkungan dan hubungan sosial dengan persentase $59,46 \%, 60,81 \%$, dan $67,57 \%$, sedangkan sebagian besar lansia pada domain psikologis dan gizi memiliki kualitas hidup yang baik dengan persentase $55,40 \%$ dan $91,89 \%$. Rata-rata kualitas hidup semua domain pada subjek di Desa Ciherang lebih tinggi dibandingkan subjek di Desa Jambu. Terdapat perbedaan signifikan pada domain kesehatan fisik, lingkungan dan hubungan sosial $(\mathrm{p}<0,05)$, tetapi tidak terdapat perbedaan signifikan pada domain psikologis dan gizi antara lansia di Desa Ciherang dan Desa Jambu ( $p>0,05)$.

Terdapat hubungan positif dan signifikan pada status gizi dengan kualitas hidup domain kesehatan fisik ( $\mathrm{p}=0,017 \mathrm{r}=0,196)$ dan lingkungan $(\mathrm{p}=0,035 \mathrm{r}=0,174)$, artinya semakin baik 
Tabel 4. Sebaran Subjek Berdasarkan Domain Kualitas Hidup

\begin{tabular}{|c|c|c|c|c|c|c|c|c|c|c|c|}
\hline \multirow{3}{*}{ Kualitas Hidup } & \multicolumn{4}{|c|}{ Ciherang } & \multicolumn{6}{|c|}{ Jambu } & \multirow{3}{*}{$\mathbf{p}$} \\
\hline & \multicolumn{2}{|c|}{ Kurang } & \multicolumn{2}{|c|}{ Baik } & \multirow{2}{*}{$\begin{array}{l}\text { Rata- } \\
\operatorname{rata} \pm \text { SD }\end{array}$} & \multicolumn{2}{|c|}{ Kurang } & \multicolumn{2}{|c|}{ Baik } & \multirow{2}{*}{$\begin{array}{c}\text { Rata- } \\
\text { rata } \pm \text { SD }\end{array}$} & \\
\hline & $\mathbf{n}$ & $\%$ & $\mathbf{n}$ & $\%$ & & $\mathbf{n}$ & $\%$ & $\mathbf{n}$ & $\%$ & & \\
\hline Kesehatan fisik & 25 & 33,79 & 49 & 66,21 & $66 \pm 15$ & 44 & 59,46 & 30 & 40,54 & $54 \pm 9$ & 0,002 \\
\hline Psikologis & 28 & 37,78 & 46 & 62,16 & $59 \pm 12$ & 33 & 44,60 & 41 & 55,40 & $57 \pm 14$ & 0,405 \\
\hline Lingkungan & 31 & 41,89 & 43 & 58,11 & $59 \pm 14$ & 45 & 60,81 & 29 & 39,19 & $51 \pm 8$ & 0,022 \\
\hline Hubungan sosial & 36 & 48,69 & 38 & 51,35 & $63 \pm 18$ & 50 & 67,57 & 24 & 32,43 & $58 \pm 11$ & 0,020 \\
\hline Gizi & 3 & 4,05 & 71 & 95,95 & $78 \pm 12$ & 6 & 8,11 & 68 & 91,89 & $71 \pm 11$ & 0,304 \\
\hline
\end{tabular}

Tabel 5. Hubungan antar Variabel

\begin{tabular}{lcccccc}
\hline \multirow{2}{*}{$\begin{array}{c}\text { Domain Kualitas } \\
\text { Hidup }\end{array}$} & \multicolumn{2}{c}{ Status gizi } & \multicolumn{2}{c}{ Riwayat penyakit } & \multicolumn{2}{c}{ Penyakit satu bulan terakhir } \\
\cline { 2 - 7 } & $\mathbf{p}$ & $\mathbf{r}$ & $\mathbf{p}$ & $\mathbf{r}$ & $\mathbf{p}$ & $\mathbf{r}$ \\
\hline Kesehatan fisik & $0,017^{*}$ & 0,196 & 0,075 & 0,147 & $0,046^{*}$ & 0,165 \\
Psikologi & 0,107 & 0,133 & 0,358 & 0,076 & 0,994 & 0,001 \\
Lingkungan & $0,035^{*}$ & 0,174 & 0,144 & 0,121 & 0,287 & 0,091 \\
Hubungan sosial & 0,115 & 0,130 & $0,009^{*}$ & 0,213 & $0,007^{*}$ & 0,220 \\
Gizi & 0,519 & 0,053 & 0,348 & 0,078 & 0,942 & 0,006 \\
\hline
\end{tabular}

*Berhubungan signifikan pada $\mathrm{p}<0,05$

status gizi lansia maka semakin baik pula kualitas hidupnya. Terdapat hubungan signifikan riwayat penyakit dengan kualitas hidup domain hubungan sosial $(\mathrm{p}=0,009 \mathrm{r}=0,213)$ dan terdapat hubungan signifikan penyakit satu bulan terakhir dengan kualitas hidup domain kesehatan fisik $(\mathrm{p}=0,046$ $\mathrm{r}=0,165)$ dan hubungan sosial $(\mathrm{p}=0,007 \mathrm{r}=0,220)$. Hubungan tersebut berbanding lurus, artinya semakin baik kesehatan lansia maka semakin baik pula kualitas hidupnya (Tabel 5).

\section{PEMBAHASAN}

Proporsi lansia dan lansia yang berstatus cerai mati pada penelitian ini lebih banyak dialami oleh lansia perempuan. Penelitian ini sesuai dengan data BPS 2015 dan menunjukkan bahwa usia harapan hidup perempuan lebih tinggi dibandingkan laki-laki sehingga persentase lansia perempuan yang berstatus cerai mati lebih banyak dibandingkan lansia laki-laki. ${ }^{21}$ Tingkat pendidikan lansia di Desa Ciherang dan Desa Jambu relatif masih rendah. Rendahnya tingkat pendidikan lansia dapat mempengaruhi aksesibilitas ke fasilitas kesehatan. ${ }^{1}$ Pendidikan merupakan salah satu faktor yang mempengaruhi kualitas hidup lansia, dengan tingginya jenjang pendidikan maka pengetahuan seseorang akan sadar gizi berpengaruh terhadap kualitas hidup. ${ }^{19}$ Orang yang berpendidikan pada umumnya lebih sadar mengenai kehidupan, hubungan sosial dan lingkungan sekitarnya. ${ }^{20}$ Pendidikan mempengaruhi jenis pekerjaan, pekerjaan dengan tingkat penghasilan yang berbeda dapat mempengaruhi kualitas hidup lansia. ${ }^{19}$ Perbedaan suku pada penelitian ini menyebabkan adanya perbedaan pada kebiasaan makan, kebiasaan makan akan mempengaruhi status gizi. ${ }^{21}$

Status gizi adalah ekspresi dari keadaan keseimbangan gizi dalam bentuk variabel tertentu. ${ }^{22}$ Hasil MNA menunjukkan sebagian lansia mengalami penurunan asupan makan dan kurang mengonsumsi cairan. Penurunan asupan makan pada lansia disebabkan oleh masalah fisiologis seperti terjadi gangguan pencernaan penurunan sensitifitas indera perasa dan penciuman, malabsorpsi zat gizi serta beberapa kemunduran fisik lainnya dapat menyebabkan rendahnya asupan zat gizi. ${ }^{23}$ Lansia dengan risiko malnutrisi di Desa Jambu lebih banyak dibandingkan Desa Ciherang, jika lansia tersebut tidak diberikan penanganan yang baik maka akan menyebabkan terjadinya malnutrisi. Malnutrisi merupakan keadaan defisiensi, kelebihan atau ketidakseimbangan protein, energi dan zat gizi lain yang dapat mengganggu fungsi tubuh. Malnutrisi pada lansia dapat berupa obesitas, malnutrisi energi protein dan defisiensi vitamin dan mineral. ${ }^{24}$ Keadaan gizi seseorang mempengaruhi 
penampilan, pertumbuhan dan perkembangannya, kondisi kesehatan serta ketahanan tubuh terhadap penyakit. Obesitas berkaitan dengan penyakit diabetes, penyakit jantung, tekanan dan darah tinggi. ${ }^{25}$

Status kesehatan lansia dipengaruhi oleh ada tidaknya penyakit dalam tubuh lansia. Lansia yang tidak memiliki keluhan penyakit akan mampu melakukan aktivitas dan kegiatan. ${ }^{3}$ Riwayat penyakit subjek antara lain hipertensi, ginjal, jantung, diabetes, gangguan tiroid dan lainnya (asma, asam urat dan rematik). Penyakit tersebut masuk dalam kategori penyakit tidak menular yang sering terjadi pada lansia karena fungsi fisiologis yang mengalami penurunan akibat proses degeneratif. Masalah degeneratif dapat menurunkan daya tahan tubuh sehingga rentan terkena infeksi penyakit menular. Penyakit satu bulan terakhir pada subjek yaitu hipertensi, rematik, asam urat, sakit kepala, magh, batuk, demam dan lainnya (asma, pegal-pegal). Beberapa lansia memiliki penyakit lebih dari satu, karena lansia mengalami masalah kesehatan karena penurunan fungsi fisik dan mental. Masalah kesehatan ini dapat menyebabkan menurunnya kualitas hidup lansia. ${ }^{26}$ Tidak ada perbedaan status kesehatan antara lansia di Desa Ciherang dan Desa Jambu, hal ini dikarenakan persentase status kesehatan lansia di kedua Desa tersebut tidak jauh berbeda.

Kualitas hidup adalah kondisi fungsional lansia yang meliputi kesehatan fisik, kesehatan psikologis, dukungan sosial, dan kondisi lingkungan. ${ }^{7}$ Kualitas hidup merupakan konsep dari beberapa dimensi yang mencakup kesehatan fisik, mental, psikologis dan kesejahteraan, terkadang juga dapat dikatakan sebagai kepuasan hidup. ${ }^{8}$ Kualitas hidup yang baik dimiliki seseorang dengan kebiasaan mengatur pola makan, gaya hidup yang baik, rutin memeriksakan kesehatan dan rajin mengikuti program penyuluhan, sedangkan kualitas hidup kurang dimiliki seseorang dengan kebiasaan yang dapat meningkatkan risiko paparan penyakit. ${ }^{27}$ Dalam segi kesehatan, kualitas hidup dapat disamakan dengan keadaan kesehatan, fungsi fisik tubuh, perceived health status, kesehatan subjektif, persepsi mengenai kesehatan, kognisi individu, ketidakmampuan fungsional, gangguan psikiatri dan kesejahteraan. ${ }^{28}$

Rata-rata kualitas hidup domain fisik di Desa Ciherang lebih tinggi dibandingkan dengan Desa
Jambu. Hal ini dikarenakan lansia yang sakit di Desa Ciherang lebih sedikit dibandingkan dengan lansia di Desa Jambu, selain itu penyakit hipertensi di Desa Jambu lebih banyak dibandingkan Desa Ciherang. Hipertensi merupakan penyakit kronis yang menimbulkan implikasi organ dan memberikan pengaruh pada kehidupan sosial ekonomi dan kualitas hidup domain kesehatan fisik. Penyakit kronis yang diikuti dengan konsumsi obat-obatan (obat hipertensi) mempengaruhi kualitas hidup. Menurut Soni et al., kualitas hidup lansia yang menderita hipertensi lebih rendah dibandingkan lansia yang memiliki tensi normal, karena memberikan pengaruh buruk terhadap vitalitas, fungsi sosial, kesehatan mental dan psikologis. ${ }^{29}$

Lebih dari separuh lansia di Desa Jambu memiliki kualitas hidup yang kurang pada domain lingkungan dan hubungan sosial. Kualitas hidup yang kurang ditandai dengan kurang aktifnya lansia dalam kegiatan sosial, berkumpul dengan teman-teman dan kurangnya dukungan dari keluarga, selain itu beberapa lansia merasa lingkungan tempat tinggalnya kurang sehat, penghasilan kurang mencukupi dan informasi yang didapat kurang. Lansia di Desa Ciherang lebih sering memanfaatkan pelayanan kesehatan dan transportasi, serta rutin melakukan pengajian sehingga lansia dapat berkumpul dan berkomunikasi dengan sesama lansia. Hal ini yang menyebabkan ratarata kualitas hidup pada domain lingkungan dan hubungan sosial lebih tinggi dibandingakan lansia di Desa Jambu.

Rata-rata kualitas hidup domain psikologis pada lansia di dua desa tidak berbeda, lebih dari separuh lansia di dua desa memiliki kualitas hidup yang baik pada domain psikologis, tetapi terdapat beberapa lansia yang merasa kesepian, tidak berarti dan kepuasaan diri yang kurang. Hal ini disebabkan karena terjadinya perubahan psikologis pada lansia seperti perasaan rendah diri apabila dibandingkan dengan orang yang lebih muda, berkurangnya penampilan, perubahan cara hidup dan sadar akan kematian. ${ }^{30}$ Hampir seluruh lansia di kedua desa memiliki kualitas hidup yang baik pada domain gizi, karena lansia di Desa Ciherang dan Desa Jambu merasa cukup kenyang dalam mengonsumsi makanan setiap hari, memiliki banyak pilihan makanan, masih mampu mengunyah makanan dan menyiapkan makanan sendiri. 
Kualitas hidup lansia akan semakin buruk dengan bertambahnya usia. ${ }^{31}$ Pertambahan usia dapat menyebabkan perubahan dalam cara hidup, perubahan dalam hal ekonomi, penyakit kronis, kekuatan fisik, perubahan mental, dan psikososial. ${ }^{19}$ Kualitas hidup yang baik dapat dilihat dari status gizi subjek dengan kategori gizi baik. Pemenuhan kebutuhan gizi yang baik dapat membantu proses beradaptasi dengan perubahan yang dialami dan dapat menjaga kelangsungan pergantian sel-sel tubuh sehingga dapat memperpanjang usia. $^{32}$

Terdapat hubungan positif status gizi dengan kualitas hidup domain kesehatan fisik dan lingkungan. Status gizi kurang ataupun lebih dapat mengakibatkan keterbatasan dalam aktivitas lansia sehingga mempengaruhi kualitas hidup lansia domain kesehatan fisik. Penyebab tidak langsung masalah gizi adalah faktor lingkungan, pendapatan, dan ketersediaan informasi sehingga status gizi pada lansia berhubungan dengan kualitas hidup domain lingkungan. Sejalan dengan penelitian Luger et al., yang menunjukkan adanya hubungan status gizi dengan kualitas hidup domain kesehatan fisik dan lingkungan. ${ }^{33}$ Berbeda dengan penelitian Artacho et al., yang menunjukkan terdapat hubungan status gizi dengan domain kesehatan fisik, lingkungan, psikologis dan hubungan sosial sedangkan menurut Perry L dan Mclaren S terdapat hubungan antara status gizi dan kualitas hidup domain psikologis, lingkungan dan makanan. ${ }^{34,35}$

Terdapat hubungan positif riwayat penyakit dengan domain hubungan sosial dan terdapat hubungan positif penyakit satu bulan terakhir dengan domain kesehatan fisik dan hubungan sosial. Penyakit pada lansia mempengaruhi kualitas hidup dimensi kesehatan fisik karena membatasi lansia dalam melakukan aktivitas. ${ }^{36}$ Aktivitas yang terbatas menyebabkan lansia jarang berada di luar rumah untuk mengikuti kegiatan dan berinteraksi, selain itu lansia yang memiliki penyakit akan sulit berkonsentrasi, mudah marah, merasa tidak nyaman, sehingga berdampak pada hubungan sosial. Sejalan dengan penelitian Kumar et al. yang menunjukkan hubungan penyakit dengan domain kesehatan fisik dan hubungan sosial. ${ }^{37}$ Berbeda dengan penelitian Gureje et al., terdapat hubungan status kesehatan dengan kualitas hidup domain kesehatan fisik, lingkungan, psikologis dan hubungan sosial, sedangkan menurut Miranda et al., kualitas hidup lansia yang menderita penyakit kronis dipengaruhi oleh domain kesehatan fisik dan psikologis. ${ }^{38,28}$

\section{KESIMPULAN DAN SARAN}

Terdapat perbedaan signifikan pada karakteristik subjek dalam hal status perkawinan, pendidikan, pekerjaan, dan status tinggal antara lansia di Desa Ciherang dan Desa Jambu. Terdapat perbedaan signifikan pada status gizi lansia sedangkan tidak terdapat perbedaan pada status kesehatan lansia di Desa Ciherang dan Desa Jambu. Terdapat perbedaan signifikan pada kualitas hidup domain kesehatan fisik, lingkungan dan hubungan sosial. Terdapat hubungan status gizi dengan kualitas hidup domain kesehatan fisik dan lingkungan sedangkan status kesehatan berhubungan dengan kualitas hidup domain kesehatan fisik dan hubungan sosial. Lansia diharapkan lebih banyak berpartisipasi aktif dan memantau kesehatan agar terhindar dari risiko kurang gizi dan berbagai penyakit.

\section{DAFTAR PUSTAKA}

1. Kemenkes RI. Gambaran Kesehatan Lanjut Usia di Indonesia. Buletin Jendela Data dan Informasi Kesehatan. Jakarta: Kementerian Kesehatan RI; 2013.

2. BPS. Statistik Penduduk Lanjut Usia 2014. Jakarta: Badan Pusat Statistik; 2015.

3. Fatmah. Gizi Usia Lanjut. Jakarta: Erlangga; 2010.

4. Yuliati A, Baroya N, Ririanty M. Perbedaan Kualitas Hidup Lansia yang Tinggal di Komunitas dengan di Pelayanan Sosial Lanjut Usia. Jurnal Pustaka kesehatan. 2014;2(1):87-94.

5. WHO. The World Health Organization Quality of Life (WHOQOL)-BREF. Geneva: World Health Organization; 2004.

6. Brown J, Bowling A, Flyn T. Models of Quality of Life: A Taxonomy, Overview and Sistematic Review of the Literatur. European Forum on Population Ageing Research. 2004; 6-8.

7. WHO.WHOQOL Measuring Quality of Life. Division of Mental Health and Prevention of Substance Abuse. Geneva: World Health Organization; 1997. 
8. Boggatz T. Quality of Life in Old Age-a Concept Analysis. Inteernational Journal of Older People Nursing. 2014; 55-69.

9. Abbasimoghadam MA, Dabiran S, Safdari R, Djafarian K. Quality of Life and Its Relation to Socio Demographic Factors Among Elderly People Living in Tehran. Geriatri Gerontol Int. 2009; 9(3):270-275.

10. Salim OC, Sudharma NI, Kusumaratna RK, Hidayat A. Validitas dan Reabilitas World Health Organization Quality of Life-BREF untuk Mengukur Kualitas Hidup Lanjut Usia. Universa Medicina. 2007; 26(1):27-38.

11. Bair EC. The Impact of Nutritional Status on the Health and Quality of Life of Older Adults. Journal of Gerontology. 2011; 56A(2):54-64.

12. Vailas LI, Nitzke SA, Becker M, Gast J. Risk Indicators for Malnutrition Are Associated Inversely with Quality of Life for Participants in Meal Programs for Older Adults. Journal of the American Dietetic Association. 1998; 98(5):548-553.

13. Elsawy B dan Kim EH. Physical Activity Guidelines for Older Adults. American Academy of Family Physician. 2010;81(1):55-59.

14. Meilianingsih L. Hubungan Pola Makan dengan Kejadian Anemia Pada Lansia di Kecamatan Cicendo Kota Bandung. Jurnal Kesehatan Kartika Stikes A Yani. 2011;17-28.

15. Yuliantini E, Maigoda TC. Impact of Sports and Nutrition Counseling to Blood Pressure and Nutritional Status Based on Waist Circumference in Hypertensive Patients at Bengkulu Municipality. Buletin Penelitian Sistem Kesehatan. 2011;14(3):290-300.

16. Aguero S, Canete S, D'Ardaillon P, Johns CP. Association of Intake Macro and Micronutrients with Life Quality of Life in Elderly. Nutricion Hospitalaria. 2015; 31(6):2578-2582.

17. BPS. Survei Demografi dan Kesehatan Indonesia. Jakarta: Badan Pusat Statistik; 2014.

18. Vellas B, Villars H, Abellan G, Soto ME. Overview of the MNA ${ }^{\circledR}$-Its History and Challenges/Discussion. The journal of nutrition, health \& aging. 2006;10(6):456-465.

19. Aghamolaei T, Tavafian SS, Zare S. Determinants of Health Related Quality of Life on People Living in Bandar Abbas, Iran. Iranian Journal Public Health. 2011;40(2):128-135.
20. Abdullah S, Nathan R. Health Status and Quality of Life Among Older Adults in Rural Tanzaania. Global Health Action Suplement. 2010;3(2):145-152.

21. Almerico GM. Food and Identity: Food Studies, Cultural, and Personal Identity. Journal of International Business and Cultural Studies. 2014;8(1):1-7.

22. Hardinsyah dan Supariasa IDN. Ilmu Gizi Teori dan Aplikasi. Jakarta: EGC; 2016.

23. Irianto K. Gizi Seimbang dalam Kesehatan Reproduksi. Bandung: Alfabeta; 2014.

24. Pai MK. Comparative Study of Nutritional Status of Elderly Population Living in the Home for Aged vs Those Living in The Community. Biomedical Research. 2011;22(1): 120-126.

25. Johansson, L, Sidenvall, B, Malmberg, Christensson L. Who Will Become Malnourished? A Prospective Study of Factors Associated with Malnutrition in Older Persons Living at Home. Journal of Nutrition, Health \& Aging. 2009; 13:855-861.

26. Bishak YK, Payaho L, Poughasem B, dan Jafrabadi MA. Assesing the Quality of Life in Elderly People and Related Factors in Tabriz, Iran. Journal of Caring Sciences. 2014; 3(4): 257-263.

27. Notoatmodjo S. Kesehatan Masyarakat Ilmu dan Seni. Jakarta: PT. Rineka Cipta; 2007.

28. Miranda de Nobrega TC, Jaluul O, Machado AN, Paschoal SMP, Jacob Filho W. Quality of Life and Multimorbidity of Elderly Outpatients. Clinics. 2009;64(1):45-50.

29. Soni RK, Porter AC, Lash JP, Unruh ML. Health-related quality of life in hypertension, chronic kidney disease, and coexistent chronic health conditions. ACKD. 2010; 17(4):e17-e26.

30. Istiany A dan Rusilanti. Gizi Terapan. Bandung: Rosdakarya; 2012.

31. Datta D, Datta PP, dan Majumdar KK. Association of Quality of Life of Urban Elderly with Socio-Demographic factors. International Journal of Medicine and Public Health. 2015; 5(4):274-278.

32. Widiyanto. Strategi Peningkatan Kualitas Hidup Manusia di Indonesia. Jakarta: Erlangga; 2007. 
33. Luger E, Haider S, Kapan A, Scindler K, Lackninger C, Dorner TE. Association between nutritional status and quality of life in (pre)frail community-dwelling older persons. The Journal of Frailty \& Aging. 2016; 5(3): 141-148.

34. Artacho R, Lujano C, Vico ABS, Sanchez V, Calvo G, Bouzas PR dan Lopez R. Nutritional Status in Chonically-Ill Elderly Patients, Its Related to Quality of Life?. The Hournal of Nutrition, Health and Agieng. 2014; 18(2): 192-197.

35. Perry L dan Mclaren S. An Exploration of Nutrition and Eating Disabilities in Relation to Quality of Life at 6 Months
Post-Stroke. Health \& Social Care in the Community. 2004;12:288-297.

36. Megari K. Quality of Life in Chronic Disease Patients. Health Psychol. 2013; 1(e27):141148.

37. Kumar G, Majumdar A dan Pavithra G. Quality of Life (QOL) and Its Associated Factors Using WHOQOL-BREF Among Elderly in Urban Puducherry, India. Journal of Clinical and Diagnostic Research. 2014;8(1):54-57.

38. Gureje O, Kola L, Afolabi E dan Olley BO. Determinants of Quality of Life of Elderly Nigerians: Results from the Ibadan Study of Agieng. African Journal of Medicine and Medical Science. 2008; 37(3): 239-247. 